NBER WORKING PAPER SERIES

\author{
ARGENTINA : \\ DEBT AND MACROECONOMIC INSTABILITY
}

Rudiger Dornbusch

Juan Carlos de Pablo

Working Paper No. 2378

NATIONAL BUREAU OF ECONOMIC RESEARCH 1050 Massachusetts Avenue

Cambridge, MA 02138

September 1987

The research reported here is part of the NBER's research program in International Studies. Any opinions expressed are those of the authors and not those of the National Bureau of Economic Research. 
NBER Working Paper \#2378

September 1987

\author{
Argentina: \\ Debt and Macroeconomic Instability
}

\title{
ABSTRACT
}

The paper reviews the Argentine debt experience in the past ten years. The emphasis is on the interaction between relative prices, financial instability, budget deficits, inflation and debt accumulation. A longer run perspective shows that the continuing fiscal problems have stood in the way of investment and growth.

Rudiger Dornbusch E52-357 MIT Cambridge, Mass. 02139 (617) 253-3648
Juan Carlos de Pablo Catholic University of Argentina Buenos Aires 


\section{ARGENTINA: DEBT AND MACROECONOMIC INSTABILITY 1}

\author{
Rudiger Dornbusch \\ Massachusetts Institute of Technology \\ and \\ National Bureau of Economic Research
}

\author{
Juan Carlos de Pablo \\ Catholic University \\ of Argentina
}

In 1985, after 40 years of financial instability, Argentina reached once again near-hyperinflation conditions. Budget deficits were the immediate cause, but the deeper roots nust be seen in ill-fated policy experiments of the 1970s. The destructive pendulum between populists and market-oriented reformists has meant that much of national wealth is held abroad, taxes are paid by only few and the general atmosphere is one of scepticism about everything Argentinian. Mallon and Sourrouille (1975) have drawn attention to this steady conflict when they write

"Decision makers in Argentina have quite consistently attempted to adopt policy positions that seemed designed to tear society apart rather than to forge new coalitions.... Major policy disagreements in modern Argentina history have their main roots in the conflict between two divergent streams of thought: 1 iberalism of the British Manchester School variety and what can be called national populism... In general the liberals have stood for the virtues of a society open to international opportunities and influences, whereas the national populists have emphasized indigenous, autonomous development."

\footnotetext{
${ }^{1}$ This paper represents an overview of a longer study on Argentine debt problems prepared as part of the NBER research project on developing country debt.
} 
Our study investigates the interaction between domestic macroeconomic instability and external constraints. We study these relationships by focusing on the past decade in which four very different periods can be distinguished.

- The Martinez de Hoz period of the 1970s (march 76-march 81) when external debts were accumulated in the context of an incompatible mix of policies: large, persistent deficits, a strongly overvalued currency and liberalization of capital flows.

- The period running from the end of the 1970 s to the hyperinflation. In this period debt and foreign exchange problems, war and domestic politics, are the reasons for an inflation explosion.

- The Austral stabilization plan.

- The post-Austral quest for a resumption of growth.

\section{A Longrun Perspective}

Although we only focus on the past ten years we place our analysis in a longer run context. This is appropriate since debt problems and financial crises are at least 100 years old in Argentina. One hundred years ago Argentina's inability to service foreign the debt nearly brought down the City of London in the famous Baring panic of 1890; the famous Tornquist monetary reform dates back to 1899 .

It is important to view developments in this long term perspective because it highlights how Argentina has lost its position in the world economy steadily during this century. ${ }^{2}$ Carlos Diaz Alejandro (1970,p.1) reminds us of this decline:

"It is common nowadays to lump the Argentine economy in the same category with the economies of other Latin American nations. Some

${ }^{2}$ See Ford (1983), Williams (1971) and Diaz Alejandro (1970) for Argentine economic history prior to World War II. 
opinion even puts it among such less developed nations as India and Nigeria. Yet most economists writing during the first three decades of this century would have placed Argentina among the most advanced countries--with Western Europe, the United States, Canada and Australia. To have called Argentina "underdeveloped" in the sense that word has today would have been considered laughable."

If in 1900 Argentina had a U.S. standard of living then the decline has been long and deep. Summers and Heston (1985) estimate that in 1950 Argentina had only 41 percent of the U.S. standard of living (against 80 percent in Australia and Canada). By 1985 the standard of living had slipped to only 30 percent of the U.S. level. Figure 1 shows the level of per capita real income in Argentina over the past 45 years.

There is a striking difference between the steady expansion of the thirty years to 1975 and the stagnation and decline that have occurred since then. The contrast could not be stronger: From 1945 to 1975 per capita income grew at an annual rate of 1.7 percent. From 1975 to 1985 it fell at an annual rate of 1.7 percent.

The other dimension in which Argentinian performance has shown a dramatic deterioration is inflation and fiscal stability. Of course, there have been frequent precedents of massive inflation and depreciation. But the experience of the past decade, with two near-hyperinflations stands out. In 1899 Banker's Magazine already reported of South Americans and their currency: ${ }^{3}$

"... [they] are always in trouble about their currency. Either it is too good for home use, or, as frequently happens, it is too bad for foreign

${ }^{3}$ Quoted by Cardoso (1987) and Ford (1983, p.92.) 


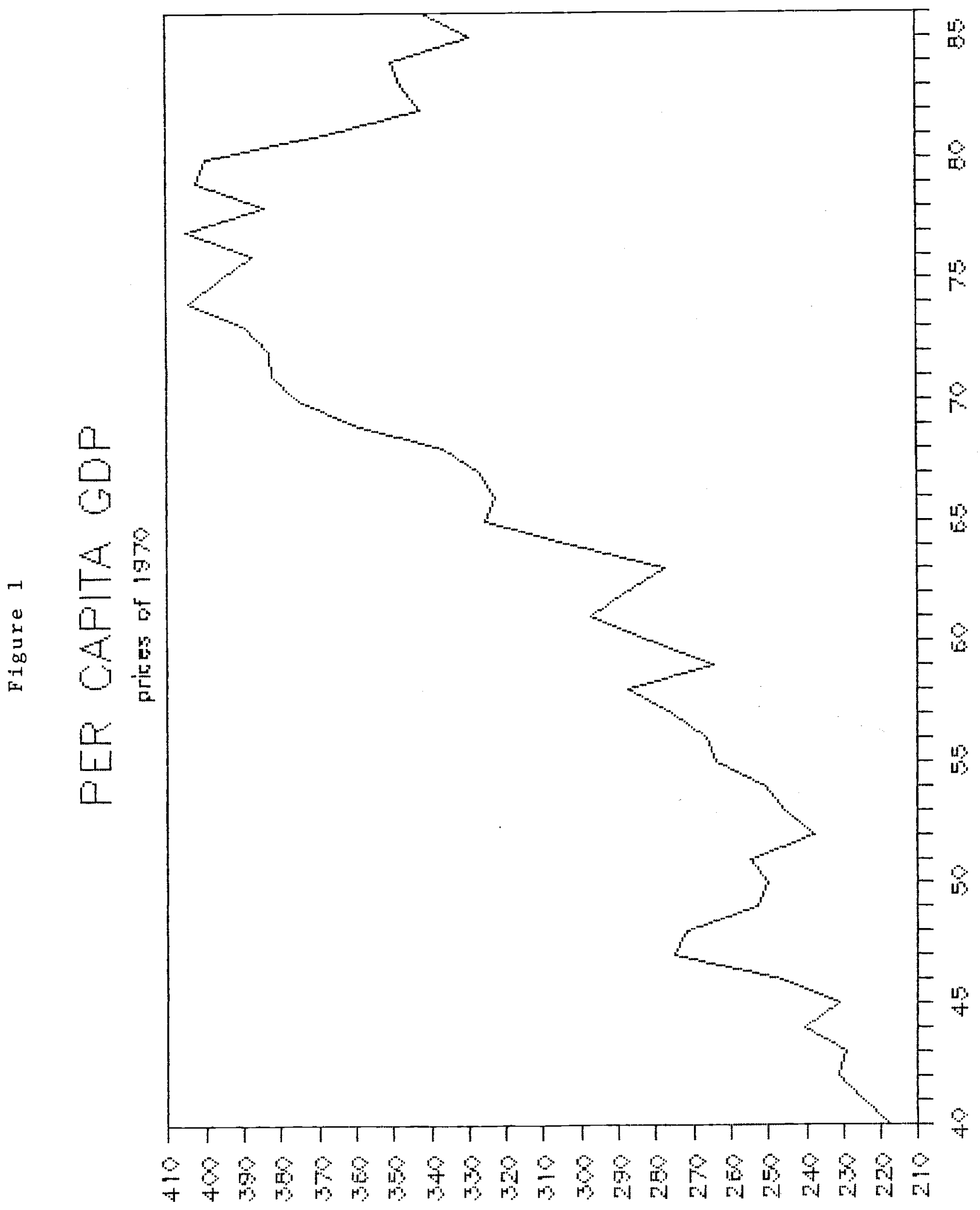


exchange. Generally they have too much of it, but their own idea is that they never have enough. . the Argentines alter their currency almost as frequently as they change presidents.. No people in the world take a keener interest in currency experiments than the Argentines."

The experience with the destruction of the financial system in the past $\mathrm{fifteen}$ years has certainly reinforced that keen interest and expertise. Figure 2 shows the monthly rate of inflation since 1970. In interpreting the graph one should bear in mind that a monthly rate of inflation of 6 percent corresponds to 100 percent per year and 22 percent per month yields an annual rate of 1000 percent. Inflation passed 1000 percent both in the Peronist period of 1975-76 and again in the pre-Austral period of early 1985. At no time in the past ten years did they fall below 100 percent for any length of time.

The third broad feature that we want to draw attention to concerns the real exchange rate. This is key price in any economy and even more so in Argentina. Figure 3 shows the real exchange rate measured as the ratio of Argentine manufactured prices relative to those of her trading partners. 4

The extraordinary variations in Argentina's external competitiveness tie closely with the macroeconomic policy mistakes, capital flight induced by these mistakes and the present debt crisis. The outstanding episode, clearly apparent in Figure 3, is the real appreciation of 1979-1981. For the period 1970-78 the real exchange rate averaged 73; it increased to 108 over the next three years before declining back to an average of 75 in the 1982-86 period.

${ }^{4}$ This is the series reported regularly by Morgan Guaranty World Financial Markets., We are indebted to Rimmer de Vries for making available the historical series. 


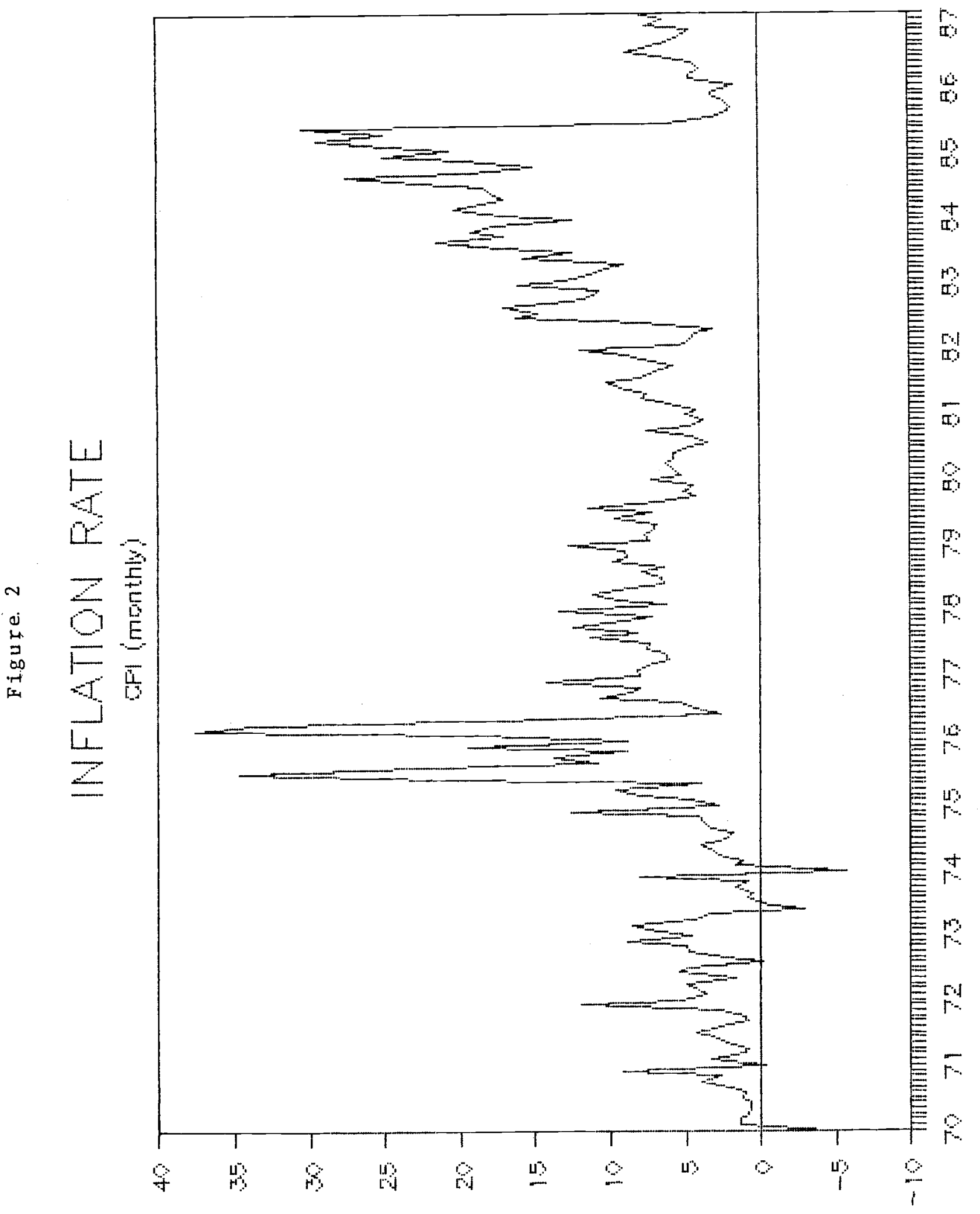




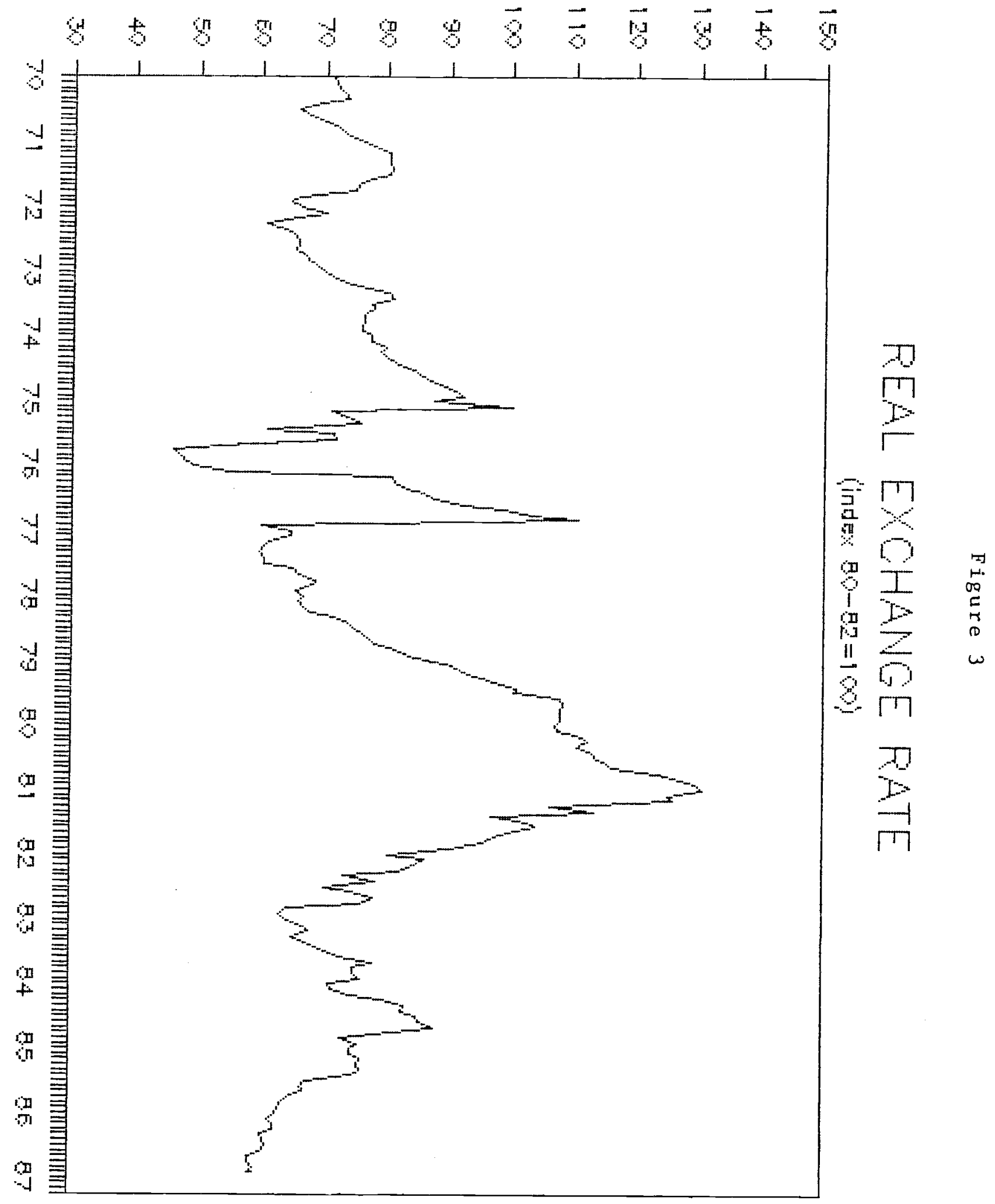


By March 1987 it had fallen to almost a third of the peak value during the period of most extreme overvaluation. The swings in the real exchange rate capture best the seesaw nature of Argentine policies. In some periods unimaginable damage is done to the productive and financial structure and then a period of repair follows where austerity and real depreciation restore the base for yet another political, fiscal or foreign exchange adventure.

Table 1 shows the debt accumulation over the past 15 years. There is considerable uncertainty about the size of the external debt prior to the late 1970s and available estimates from various official sources vary widely. Estimates of the BCRA show that debt varied between $\$ 2.5$ and 3 billion in the 1960s, starting with about the same level as it ended. But from 1970 on external debt steadily increases both for the private and for the public sector. Between 1970 and 1977 the external debt rises by $\$ 6$ billion and in the next four years by more than $\$ 30$ billion.

Table 1 Argentina' External Debt (\$Billion and Percent)

\begin{tabular}{|c|c|c|c|c|c|}
\hline & 1975 & 1978 & 1979 & 1982 & 1985 \\
\hline $\begin{array}{l}\text { Total External Debt }(\$) \\
\text { Public }(\$)\end{array}$ & $\begin{array}{l}7.9 \\
4.0\end{array}$ & $\begin{array}{r}12.5 \\
8.4\end{array}$ & $\begin{array}{l}19.0 \\
10.0\end{array}$ & $\begin{array}{l}43.6 \\
28.6\end{array}$ & $\begin{array}{l}48.3 \\
40.0\end{array}$ \\
\hline Reserves (\$) & 0.6 & 5.8 & 10.1 & 3.0 & 6.0 \\
\hline Net Debt/Exports $(\%)$ & 260 & 110 & 120 & 540 & 520 \\
\hline Debt/GDP $(\%)$ & 18.6 & 23.9 & 30.2 & 60.3 & 64.5 \\
\hline Interest Payments/GDP (\%) & 0.7 & 1.4 & 1.4 & 2.4 & 5.7 \\
\hline
\end{tabular}

Source: World Bank, BCRA and Morgan Guaranty 
With this broad overview of the past decade we now turn to a review of the principal episodes. We use these episodes to describe and explain their relevance to the debt problem, or the role of the external debt in creating domestic macroeconomic difficulties. A brief chronology of dates and important facts help place the events in context:

The Martinez de Hoz Period (3/1976-3/1981): When de Hoz assumed power as finance minister of the military government consumer prices in the previous month had increased at an annual rate of 5000 percent, output had declined sharply. The black market premium for foreign exchange exceeded 200 percent. 5 The new program was to stabilize the macroeconomy, as a first priority, and then to renovate industry and financial markets. Macroeconomic stabilization came under way quite rapidly so that inflation fell to less than 200 percent soon.

A financial reform was implemented that aimed to liberalize capital markets and link Argentina more effectively with the world capital market. Already in late 1976 foreign exchange transactions were completely liberalized on capital account and this was done so effectively that for the next four years the black market premium was zero. Figure 4 shoes the black market premium and brings out the striking interlude of free capital mobility between the Peronist period and the aftermath of the collapse of Martinez de Hoz' policies.

$50 n$ the Peronist experience see, in particular, DiTella (1983) and de Pablo $(1980,1984)$. 


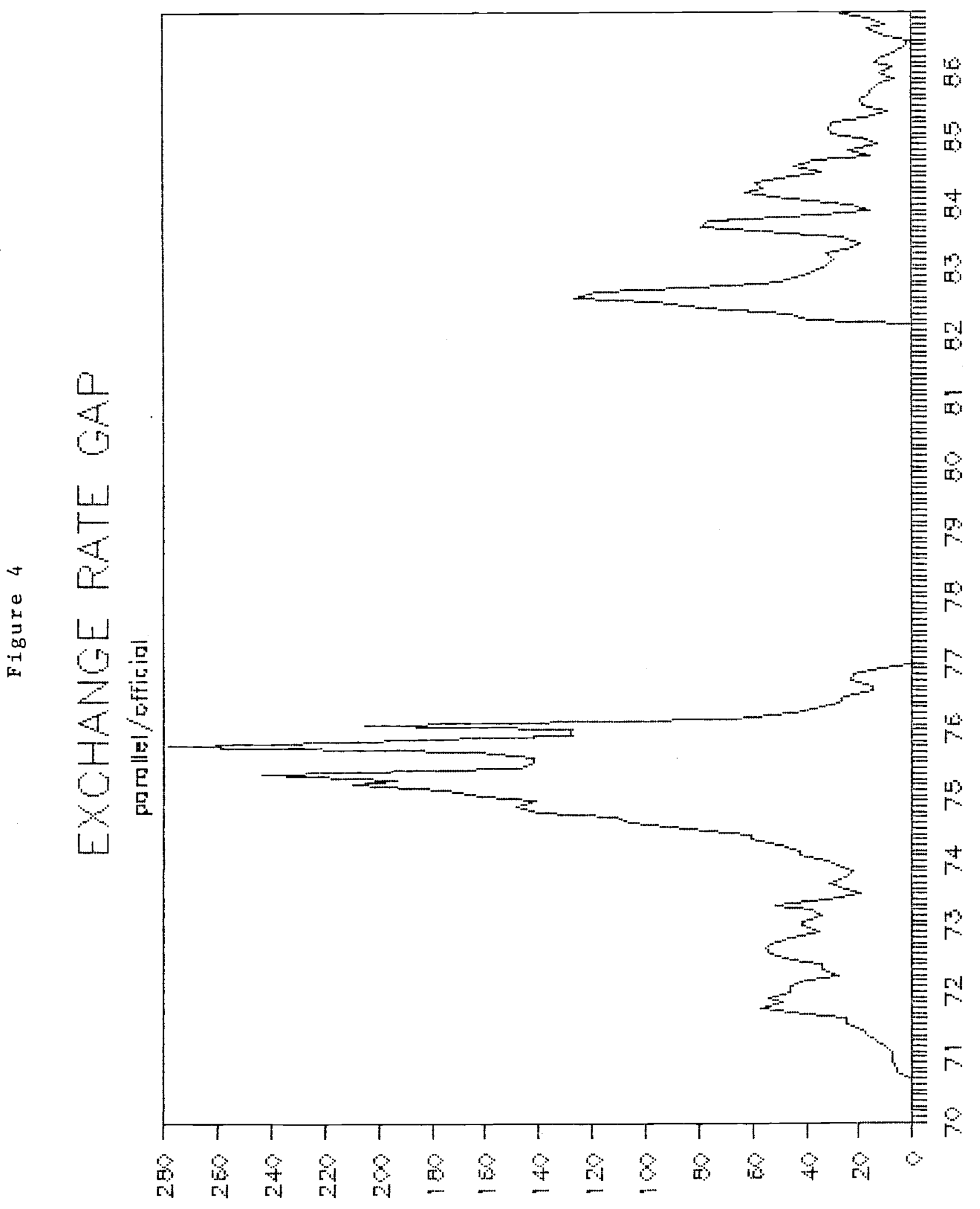


Inflation failed to decline further once it had come to the 150 percent range. To make further inroads policy makers opted for what Fernandez (1985) has called an "expectations management approach." Beginning in 1979 they pre-fixed the rate of exchange depreciation with a tablita, announcing ahead of time a gradually declining rates of depreciation. These announcements were repeated on a rolling (though shortening) basis so as to create an environment where economic agents could discern a government commitment to disinflation embodied in the time table for declining rates of exchange depreciation.

This policy was expected to reduce inflating through three separate channels. First, reduced rates of depreciation would directly reduce the rate of import price inflation. Second, reduced depreciation would enforce a discipline on domestic price setters. Third, in an environment where inflation to a large extent depended on expectations the rule or precommitment introduced as nominal anchor around which expectations could rally. Needless to say, the intellectual underpinnings of such a program relied on the belief that the "law of one price" would be strongly operative.

Inflation responded to this policy and gradually fell throughout 1980 to reach ultimately a bottom well below 100 percent. But gradually, during 1978 and 1979 , the real exchange rate appreciated because inflation consistently outpaced the rate of depreciation. We saw in Figure 3 that the cumulative overvaluation reached 50 or even 60 percent. But while the overvaluation ultimately led to capital flight and collapse of the financial system, the early stages were quite the opposite. The high interest rates-- 
relative to world rates and the preannounced rate of depreciation-- gave rise to an (almost) riskfree speculation in favor of Argentine assets. As a result private sector borrowing abroad increased to take advantage of the relatively low foreign interest rates and a massive capital inflow developed. This is shown in Table 1 in the large increase in Central Bank reserves between 1978 and 1979 and the matching increase in private external borrowing.

The trade and employment effects of the overvaluation were slow to come. Diaz Alejandro (1964) has shown that the real income effects of a real depreciation tend to be dominant in the early stages, before, substitution effects take over. For the real appreciation of 1977-80 the reverse applied: the increase in real income created an expansion in demand and thus seemed to validate the Martinez de Hoz approach by creating inflation reduction with rising real income. This factor was reinforced by the fact that trade protection, even with liberalization measures, kept the economy relatively closed which dampened the disinflation effects of the tablita but also the effects in the real sector.

By 1979-80 the overvaluation had become so extreme that financial markets increasingly took the view that depreciation would have to come sometime. Even though the government asserted that the policy would be continued, and could be financed, speculation increasingly went in the direction of dollar purchases. The regime of unrestricted capital mobility introduced in late 1976 facilitated this capital flight to the maximum. Hence, in 1979-80, the Central Bank and public sector enterprises were forced to borrow massively abroad to obtain the foreign exchange which is then sold in 
support of the exchange rate policy. Private speculators in turn bought the dollars and applied them abroad. With the round trip complete, commercial banks in New York, Zurich and Tokyo had lent to the government the resources to finance capital flight which returned to the same banks as deposits. of course, capital flight was not limited to dollar deposits. Investments in financial markets were important as was real estate abroad.

A variety of estimates is available on the accumulation of external assets by Argentines during this period. These estimates are typically formed as residuals from debt and balance of payments data. They are obtained by deducting from the recorded increase in gross external debt the current account and recorded capital flows in the form of direct investment and changes in reserves. Dornbusch (1985), for example, calculates that capital flight in $1978-82$ amounted to $\$ 23.4$ billion. In a review of various estimates the IMF (Watson et al. (1986),p.142) reports capital flight amounting to cumulatively to about $\$ 15$ billion in 1979-1981. Rodriguez (1986) estimates that between 1979 and 1982 the external assets of Argentinian's increased from $\$ 10$ billion to $\$ 34$ billion. The estimates would have to be revised upward to the extent that underinvoicing of exports and overinvoiciong of imports was a significant channel of capital flight in this period.

Both the fact of and the motivation for the wave of capital flight in the late 1970s are very clear. Unlike in other debtor countries as for example Brazil or Chile, mismanagement of the exchange rate combined with an opening of the capital account are the almost exclusive explanation for the massive debt accumulation. The particular background must be understood to 
appreciate that in Argentina's case the government has an external debt, but the private sector has matching external assets. Moreover, that process was carried further over the next few years as the government increasingly took over all external debt in the course of sustaining failing financial institutions. In 1980 about half of the debt was owed by the public sector and in 1985 that share had increased to 82 percent.

From Martinez de Hoz to Alfonsin (3/81-12/83): The end of the military government did not come easy. The Martinez de Hoz overvaluation had sown the seeds of financial destruction, but the actual unraveling came only over the next four years. The world economy contributed to the difficulties by the debt crisis: sharply declining commodity prices and much higher interest rates brought with them difficulties in servicing the external debt.

But domestic events certainly were the dominant fact. First came the undoing of the overvaluation. This started with the change of presidents: the incoming president, months before taking office, declined to comment on his exchange rate policy. This served as an obvious indication to anyone that devaluation was ahead and hence capital flight turned massive. Central Bank reserves declined by more than $\$ 5$ billion and public external debt increased sharply. Finally Martinez de Hoz was forced by his successor, not yet in office, to bring his own expectations management and credibility approach to an end by depreciating the currency.

over the next three years exchange depreciation and inflation became endemic, rising from less, than 100 percent to 600 percent at the time Alfonsin 
took office. Changes in public finance and financial markets were particularly important in this period. Exchange control was instituted once again and the black market premium reemerged (See Figure 4). The Central Bank, in an effort to assure continuing trade flows started exchange rate guarantee programs only to find that it could never hold on to the guaranteed exchange rates. As a result of losing a string of bets in the foreign exchange market the budget deteriorated dramatically. The deterioration was reinforced by financial failures that turned up in public sector hands, by the burden of external interest payments and by deteriorating terms of trade. The conflict in the South Pacific added to the loss in confidence and devastation of public finance.

The economics of this period of deterioration can be expressed in terms of a simple model of deficit finance and of financial markets. Suppose the budget deficit represents a fraction ( $g$ ) of national income and let velocity of highpowered money be an increasing function of the rate of inflation. Then it can be shown that the rate of inflation ( $p$ ) will be an increasing (and steeply rising) function of the deficit, but it will also depend on financial institutions.

$$
\mathrm{p}=(\mathrm{ag}-\mathrm{y}) /(1-\mathrm{bg})
$$

The higher the level of noninflationary velocity (a) and the more responsive velocity is to inflation as measured by the parameter (b) the more dramatic the inflation impact of budget deficits. 
This framework helps to identify the interaction of deficits, external debt service, real depreciation and financial markets in generating the inflation explosion of 1981-84. Increasing burdens of debt service, because of higher interest rates and real depreciation increased the budget deficit ratio (g) and hence raised money creation and inflation. The institutional response of financial markets to higher inflation aggravated this impact by a flight from money. The reduction in money holdings was facilitated by an increasing range of interest bearing substitutes. As these came increasingly into play velocity sharply increased ( $a$ and $b$ in (1) above increased) and that meant the inflation rate associated with a given deficit ratio also escalated.

The 1981-84 period thus represents an unraveling of the artificial stability of the late 1970s. Several events, each in itself extraordinary, combined to make the crisis large: the initial overvaluation had been extreme, the financial sector had been allowed to become overexposed in speculation, private capital flight had been massive and finally the world economy turned unfavorable just at the wrong time. Each of these factors deteriorated the budget and hence reinforced inflation.

\section{Alfonsin $(1 / 1984-)$ :}

These difficulties carried over to the beginning of the Alfonsin administration. Large real wage increases in 1983-84 created problems for the budget and for the external balance. Inflation rapidly escalated and negotiations with creditors and the IMF did not bring a solution. 
The inflation issue soon become the single most pressing problem. In early 1985 annualized monthly rates of inflation rose toward 1500 percent and beyond. The possibility of a hyperinflation was entirely realistic since the inflation process itself eroded the real value of tax collection as well as the financial system, so that ever more money needed to be created to finance an ever widening deficit. Because IMF programs seemed unable to cope with the inflation problem on a timetable and in a fashion that was politically acceptable, and because the sheer pace of disintegration was so rapid, the government considered extreme measures. The monetary reform known as the Austral Plan was just that, an all-out attempt to stop hyperinflation.

The details of the June 1985 Plan of Economic Reform which is now called the Austral plan were as follows:

- A real depreciation and a sharp increase in real public sector prices. An export and import tax, a forced saving scheme and accelerated tax collection.

- A wage-price-exchange rate freeze.

- A new money, the Austral, and a promise not to create money to finance the budget.

- A conversion scale for existing contracts that would adjust them so as to keep real burdens unchanged in the face of the unanticipated reduction in inflation.

- An IMF agreement and a rescheduling agreement with the creditors.

The stabilization immediately reduced inflation to levels of only 1-2 percent per month. The decline in inflation and the fiscal measures brought about a rapid and major shift in the budget. High real interest rates and the budget improvement created an atmosphere of at least temporary stabilization. 
The black market premium vanished. For a country that had been on the verge of hyperinflation the stabilization created an immense relief, but it also left considerable scepticism as to the possibility of stopping inflation by edict. The scepticism extended in particular to the governments ability to achieve sufficient budget control to permanently reduce the need for inflationary money creation.

But even if scepticism subsisted the stabilization proved an important political move and as such a stepping stone for ultimate and more deeply rooted stabilization. A public opinion survey presents an assessment over time of the public response to policy and management. The data are reported in Table 2 .

Table 2 Response To The Austral Plan (Percent of the sample responding positively)

\begin{tabular}{|c|c|c|c|c|c|}
\hline & $\begin{array}{l}1984 \\
\text { Dec. }\end{array}$ & May & $\begin{array}{r}1985 \\
\text { Aug. }\end{array}$ & Dec. & $\begin{array}{r}1986 \\
\text { Apr. }\end{array}$ \\
\hline Austral Plan & & & 74 & 68 & 52 \\
\hline Economic Management & 19 & 10 & 40 & 35 & 19 \\
\hline Government in general & 46 & 35 & 57 & 52 & 36 \\
\hline President Alfonsin & 72 & 64 & 74 & 71 & 64 \\
\hline
\end{tabular}

Source: La Nacion

This was not the first time Argentina had used wage-price controls to stop inflation. Indeed, in 1975-76 this was tried and the experience ended in an outburst of repressed inflation. The Austral plan has in fact not brought price stability. Inflation today is back to the $100-200$ percent range. But the 
important achievement is that inflation was brought down from more than 2000 percent and that this was accomplished without a major decline in economic activity, rise in unemployment or reduction in the purchasing power of wages.. Today there is little risk that in the near term the stabilization will collapse. That confidence makes it possible and fruitful for the government to concentrate on the two key issues: how to achieve further budget improvement so as to bring inflation down to less than 20 percent and how to restore investment and growth. External debt and debt service has a bearing on each of these questions.

Investment, Debt and the Budget:

The budget influences inflation as well as investment and growth because it influences the distribution of resources in the economy. If the government commands a large share of the resources less is left for the private sector. the government may use these resources to service the external debt via noninterest external surpluses, it can use the resources to support consumption or it can make them available for investment. The possible choices of budget strategy then are to service the debt, sustain consumption or use resources for growth. Table 3 shows the budget of the consolidated government.

Table 3 The Budget

(Percent of GDP, Budget Basis)

\begin{tabular}{|c|c|c|c|}
\hline & Expenditure & Revenues & Budget Deficit \\
\hline $\begin{array}{l}1980 \\
1981 \\
1982 \\
1983 \\
1984 \\
1985 \\
1986\end{array}$ & $\begin{array}{l}43.9 \\
49.1 \\
48.2 \\
51.6 \\
46.2 \\
47.4 \\
43.4\end{array}$ & $\begin{array}{l}36.4 \\
35.8 \\
33.1 \\
34.8 \\
33.4 \\
41.5 \\
39.8\end{array}$ & $\begin{array}{r}7.5 \\
13.3 \\
15.1 \\
16.8 \\
12.8 \\
5.9 \\
3.6\end{array}$ \\
\hline
\end{tabular}


Two points must be separated in looking at the budget impact on the economy. One is the way in which the government finances its outlays, i.e. by regular taxes, by borrowing or by the inflation tax. The second, possibly related, is how the tax system determines the allocation of resources among sectors. To illustrate, the government can replace the inflation tax with outright taxes and there will be 1 ittle effect in the aggregate except that inflation will decline. But if the inflation tax declines without an offsetting increase in outright taxes than an offsetting reduction in absorption needs to occur: either the government cuts its spending or it reduces its debt service.

For the country at large there is a tradeoff between consumption, investment and net resource transfers abroad. These points can be brought out by looking at the GDP identity:

(2) $\quad$ Output $=\underset{\text { Transfer Abroad }}{\text { Net Resource }}+$ Investment + Consumption where consumption denotes private and public sector consumption and investment, likewise, includes the private and public sector. With a given amount of resources or output available (because the economy is fully employed already) the budget and the external debt strategy now determine inflation and growth. 
To show the range of options we can look at two particular scenarios. One possibility is to keep budget adjustments to a minimum, not to interfere with consumption and yet foster growth via increased investment. That strategy requires, as (2) shows, that resource transfers abroad can no longer occur or must even be reversed. In a second scenario the government seeks both investment and continued, partial debt service. In that case the resource shortage calls for crowding out of consumption by outright taxation or by the inflation $\operatorname{tax}$.

Over the past few years crowding out of investment, not consumption has been the rule. By maintaining relatively tight money and a strongly competitive exchange rate the government has crowded out private investment, leaving resources with consumption and transfers abroad absorbing the available resources. The adverse effect of positive and often high real interest rates on investment is all the more punishing in that uncertainty about future budget trends and debt service, and hence interest rates, make it unwise to repatriate capital or risk borrowing.

Figure 5 shows the extraordinarily low rate of private investment (as a percent of GNP) in Argentina. Net investment in fact is zero or negative. With productive capacity not expanding, or even shrinking, there is no source of growth in the standard of living. Hence the question is whether the current policy mix can be sustained much longer without doing irreparable damage to the economy productive system and thus to the longrun viability of the economy. The flourishing of the underground economy is certainly a warning signal of a very undesirable trend. 


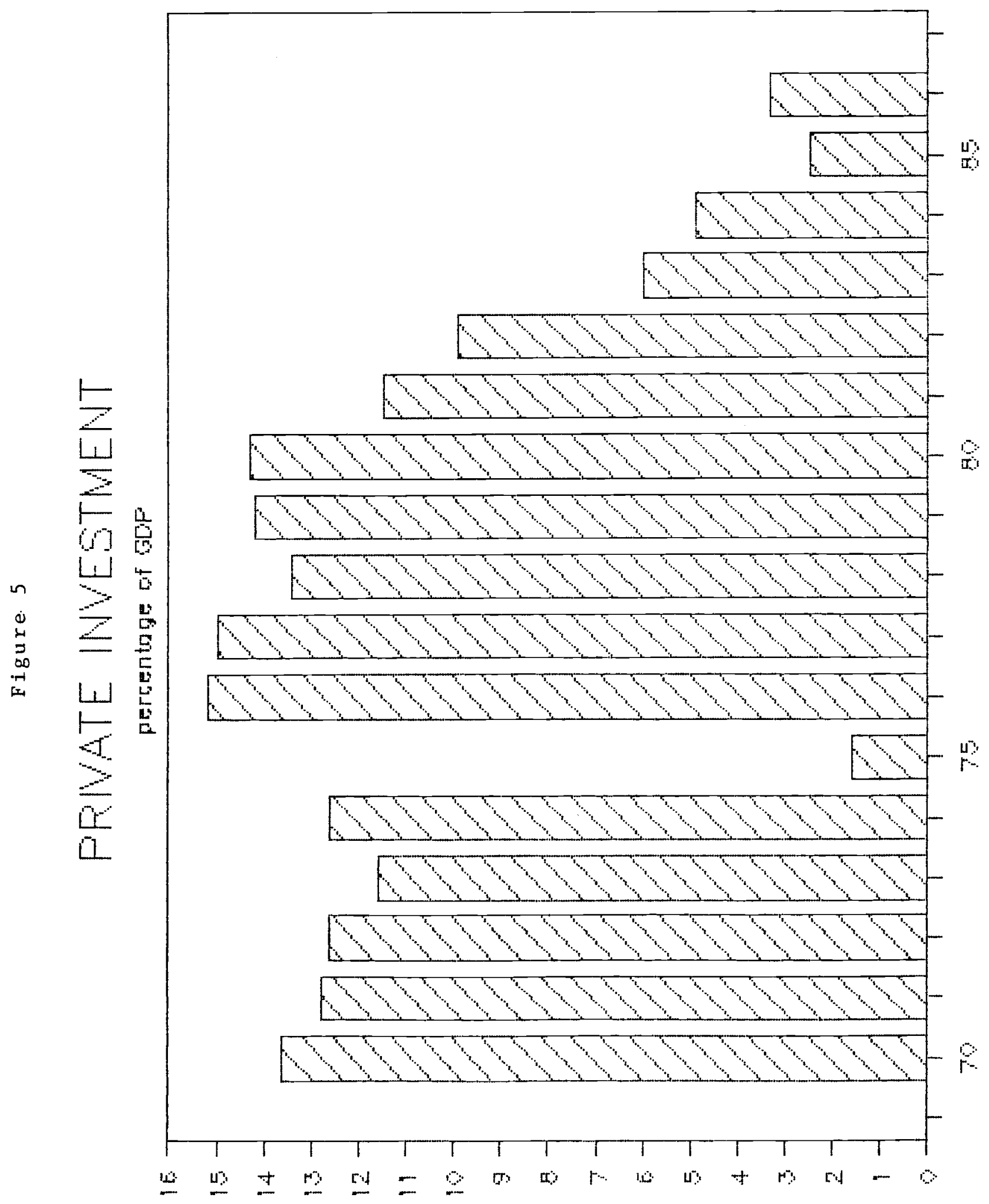


IMF programs for Argentina, in the absence of an official change in the debt strategy, anticipate that the current account deficit gradually declines as a ratio of GDP and ultimately turns toward surplus. The 1986 program, for example, anticipated that by 1990 Argentina's current account would reach a modest surplus of 0.2 percent of GDP. That means, of course, net resource transfers in the full amount of interest labilities and no "new money" except for principal. This strategy, if it is to be consistent with even moderate growth of the economy's supply side, requires a major shift in the budget to contain consumption. That can take the form of a much higher inflation tax or a much higher outright form of taxation.

Latin American leaders advocate a different scenario. They argue that net resource flows need to be reversed and that the noninterest surpluses can come down. Resources need to be transferred inward again, they argue, so that they can supplement scarce domestic saving in financing domestic investment. Such a reversal of resource flows encounters the problem of creditworthiness. If now debtor countries like Argentina experience difficulties in servicing the debt, is it plausible that yet more debt should be added. Feldstein (1986, 1987) has argued that some countries, in particular Brazil, can both borrow and grow without risking the build up of an unsustainable debt. It is difficult to see that possibility in Argentina, except in the context of a major restructuring of the public sector.

But if increased reliance is placed on external resources by reducing net transfers abroad the question must be asked how the extra room thus gained should be used. Once again a fiscal reform could translate these resources 
into growth of productive capacity. Using them for consumption would simply reduce creditworthiness and thus presage yet another financial crisis sometime in the future.

Argentina thus faces a critical juncture in respect to fiscal policy. Fiscal choices today are critical because they affect inflation and growth and because there is little room left for mistakes. The external debt service is a key variable because it presently absorbs resources that could be available for growth. But resource savings due to reduced external debt service (assuming there is no debt forgiveness) can only be used productively if fiscal reform translates them into sharply higher growth. The critical decisions to make that possible have as yet not been reached. Moreover, if capital markets are unwilling to lend on a major scale then most of the growth must be financed by reduced consumption. Thus the policy mistakes of the 1970 s directly translate into a growth crisis for the 1980 s.

The present effort to stabilize the budget and hence bring about growth and financial stability goes in its implications much beyond the economic sphere. Political and institutional instability in Argentina resemble that of the Weimar Republic and Central Europe in the 1920s or the 5 th Republic in France. The political instability in turn influences economics because it stands in the way of continuity and farsightedness of economic policies. If, as has been the case in Argentina, the average tenure of a central bank president is less than a year this is certainly not conducive to a long view. The attempt at reconstruction underway today is thus of extraordinary significance. This also implies that increased flexibility of 
external constraints associated with debt service assumes particular importance.

\section{REFERENCES}

Calvo,G. (1986) "Incredible Reforms", mimeo, University of Pennsylvania Cardoso, E. (1987) "Lat in America Debt: Which Way Now?" Challenge, May. Cavallo,D.(1984) Volver a Crecer, Buenos Aires: Sudamericana-Planeta. -.--- and Pena, A. (1983), "Deficit Fiscal, Endeudamiento del Gobierno y Tasa de Inflacion:Argentina 1940-82," in Estudios, No.26, AprilJune.

Dagnino Pastore, J. M., (1983), "Progress and Prospects for the Adjustment in Argentina," in J.Williamson (ed.), Prospects for Adjustment, Institute for International Economics, MIT Press.

diTella, G. (1983) Argentina Under Peron 1973-76, New York: St Martin's.

Diaz Alejandro, C. (1964) Exchange Devaluation in a Semi-Industrialized Country, Cambridge, Ma: MIT Press

- Essays on the Economic History of the Argentine Republic, New Haven: Yale University Press

Dornbusch, R. (1985), "External Debt, Budget Deficits and Disequilibrium Exchange Rates," in G. Smith and J.Cuddington (eds.) International Debt and the Developing Countries, World Bank.

------and Simonsen,M.(1987) Inflation Stabilization with Incomes Policy

Support, New York: Group of Thirty

Feldstein,M. (1986) "International Debt Service and Economic Growth: Simple Analytics" NBER Working Paper No. 2076.

-.--(1987) "Muddling Through is Just Fine" The Economist (London), June 27.

Fernandez,R. B. (1985) "The Expectations Management Approach to Stabilization in Argentina 1976-82" World Development, 13, No.8, August, 871-892. 
(1982) and Rodriguez, C.A. Inflacion y Estabilidad, Buenos Aires: Ediciones Macchi.

Ford, A.G. (1983) The Gold Standard 1880-1914: Britain and Argentina, (Reprint) New York: Garland.

Harberger, A. (1985) "Lessons for Debtor Country Managers and Policy Makers" in G.Smith and J. Cuddington (eds.) International Debt and The Developing Countries, Washington DC: The World Bank

Heyman,D. (1986) Tres Ensayos Sobre Inflacion y Politicas de Estabilizacion, CEPAL, Buenos Aires, Doc. 非18.

Instituto de Estudios Economicos sobre la Realidad Argentina y Latinoamericana, Estatisticas de la Evolucion Economica de Argentina. 19131984, (published in Estudios, 9, No. 39, July-September) Cordoba.

Mallon, R. and Sourrouille, J. (1975) Economic Policy Making in a Conflict Society, Cambridge, Mass.: Harvard University Press

McCarthy,D. (1987) "Argentina Towards the Year 2000" mimeo, The World Bank.

Nogues, J. (1986), "The Nature of Argentina's Policy Reforms During 1976-81" World Bank Staff Working Paper No. 765.

de Pablo, J.C. (1980) Economia Politica del Peronismo, Buenos Aires: El Cid Editor.

-----(1981), El Processo Economico, E1 Cronista Comercial.

----(1984) Politica Economica Argentina, Buenos Aires: Ediciones Macchi

Pazos, F. (1972) Chronic Inflation on Latin America, Praeger Publishers

Ramos, J. (1986) Neoconservative Economics in the Southern Cone of Latin America, 1973-83. Johns Hopkins University Press.

Rodriguez, C.A. (1983), "Politicas de Estabilizacion en la Economia Argentina, 1978-82," Cuadernos de Economia, April.

Summers, R. and A. Heston (1984) "Improved International Comparisons of Real Product and Its Composition: 1950-1980" Review of Income and Wealth, June.

Watson, M. et al. (1986) International Capital Markets, Washington DC: International Monetary Fund.

Williams, J.H. (1971) Argentine International Trade Under Inconvertible Paper Money. 1880-1900, (Reprint) New York: AMS Press 
World Bank (1987) Argentina. Economic Recovery and Growth, Report No. 6467-AR.

Table A-1

$\begin{array}{rrrrcrr}\text { 6DP } & \begin{array}{c}\text { Inflation } \\ \text { ( CPI })\end{array} & \begin{array}{c}\text { Budget } \\ \text { def./6DP }\end{array} & \begin{array}{c}\text { Non-in } \\ \text { curr.acc./6DP }\end{array} & \begin{array}{c}\text { Real exc. } \\ \text { rate }\end{array} & \begin{array}{c}\text { Terms of } \\ \text { trade }\end{array} \\ 70 & 5.4 & 21.7 & 2.0 & 0.3 & 56.7 & 106.6 \\ 71 & 3.7 & 39.1 & 4.6 & -0.6 & 49.7 & 116.4 \\ 72 & 1.9 & 64.1 & 6.1 & 0.2 & 52.9 & 125.7 \\ 73 & 3.5 & 43.8 & 6.6 & 1.5 & 58.6 & 13.4 .6 \\ 74 & 5.7 & 40.2 & 8.5 & 1.3 & 71.2 & 117.8 \\ 75 & -0.4 & 335.1 & 15.6 & -2.2 & 36.9 & 111.5 \\ 76 & -0.5 & 347.5 & 10.6 & 2.9 & 46.4 & 95.8 \\ 77 & 6.4 & 160.4 & 5.0 & 3.9 & 50.7 & 92.7 \\ 78 & -3.4 & 169.8 & 6.7 & 4.9 & 64.7 & 83.5 \\ 79 & 6.7 & 139.7 & 6.7 & -0.1 & 85.4 & 88.4 \\ 80 & 0.7 & 87.6 & 8.6 & -6.1 & 100.0 & 100.0 \\ 81 & -6.2 & 131.3 & 18.0 & -2.7 & 69.5 & 113.8 \\ 82 & -4.6 & 209.7 & 18.9 & 3.3 & 48.9 & 98.5 \\ 83 & 2.8 & 433.7 & 17.8 & 3.9 & 58.8 & 94.1 \\ 84 & 2.6 & 688.0 & 13.8 & 4.2 & 58.4 & 101.7 \\ 85 & -4.5 & 385.0 & 5.1 & 6.2 & 48.9 & 88.4 \\ 86 & 5.7 & 81.9 & - & 1.9 & 45.2 & 78.4\end{array}$


Table A-2

EXTERNAL SECTOR

(US dollars)

Current account Interex Non-int Teras of Debt/6DP Real exc. - \% of gdp payments curr.ac trade rate

$\begin{array}{rrrrrrrr}70 & -159.0 & -0.8 & -222.5 & 63.6 & 106.6 & 16.7 & 56.7 \\ 71 & -389.0 & -1.8 & -255.9 & -132.8 & 116.4 & 18.2 & 49.7 \\ 72 & -223.0 & -1.0 & -273.0 & 50.0 & 125.7 & 21.8 & 52.9 \\ 73 & 721.0 & 2.7 & -317.0 & 1038.0 & 134.6 & 20.0 & 58.6 \\ 74 & 127.0 & 0.4 & -298.0 & 425.0 & 117.8 & 20.4 & 71.2 \\ 75 & -1284.0 & -3.5 & -460.0 & -824.0 & 111.5 & 18.6 & 36.9 \\ 76 & 665.0 & 1.7 & -465.0 & 1130.0 & 95.8 & 18.6 & 46.4 \\ 77 & 1290.0 & 3.0 & -370.0 & 1660.0 & 92.7 & 19.2 & 50.7 \\ 78 & 1833.0 & 4.0 & -405.0 & 2238.0 & 83.5 & 23.9 & 64.7 \\ 79 & -537.0 & -1.0 & -493.0 & -44.0 & 88.4 & 30.2 & 83.4 \\ 80 & -4767.0 & -7.6 & -947.0 & -3824.0 & 100.0 & 37.3 & 100.0 \\ 61 & -4714.0 & -7.4 & -2965.0 & -1749.0 & 113.8 & 48.1 & 69.5 \\ 82 & -2357.0 & -3.8 & -4403.0 & 2046.0 & 98.5 & 60.3 & 48.9 \\ 83 & -2461.0 & -3.8 & -4983.0 & 2522.0 & 94.1 & 59.5 & 58.8 \\ 84 & -2391.0 & -3.5 & -5273.0 & 2888.0 & 101.7 & 60.5 & 58.4 \\ 85 & -953.0 & -1.5 & -4879.0 & 3926.0 & 88.4 & 64.3 & 48.9 \\ 86 & -2645.0 & -4.0 & -3934.0 & 1289.0 & 78.4 & - & 45.2\end{array}$

Table $A-3$

Prices $(1980=100)$

$\begin{array}{llllll}\text { Agricl } & \text { Real Public } & \text { Real } & \text { Terns of } & \text { Real Exc. } & \text { Relative } \\ \text { Nonagric } & \text { Sector Frices } & \text { kages } & \text { Trade } & \text { Rate } & \text { Price of } \\ \text { (npi) } & & & & & \text { land }\end{array}$

$\begin{array}{rrrrrrr}70 & 119.05 & 106.30 & - & 106.6 & 56.69 & 190.16 \\ 71 & 132.14 & 100.13 & 263.25 & 116.4 & 49.69 & 216.39 \\ 72 & 152.38 & 97.64 & 216.16 & 125.7 & 52.92 & 308.20 \\ 73 & 141.67 & 107.61 & 267.77 & 134.6 & 58.62 & 249.18 \\ 74 & 123.81 & 151.71 & 264.36 & 117.8 & 71.15 & 337.70 \\ 75 & 97.62 & 158.53 & 217.64 & 11.5 & 36.92 & 319.67 \\ 76 & 104.76 & 131.63 & 124.01 & 95.8 & 46.46 & 478.69 \\ 77 & 111.90 & 150.05 & 83.01 & 92.7 & 50.69 & 393.44 \\ 78 & 109.52 & 133.60 & 79.59 & 83.5 & 64.69 & 124.59 \\ 79 & 110.71 & 104.59 & 70.73 & 88.4 & 83.38 & 93.44 \\ 80 & 100.00 & 100.00 & 100.00 & 100.0 & 100.00 & 100.00 \\ 81 & 90.48 & 115.88 & 106.46 & 113.8 & 69.54 & 63.93 \\ 82 & 103.57 & 111.29 & 139.89 & 98.5 & 48.92 & 103.28 \\ 83 & 107.14 & 131.50 & 152.54 & 94.1 & 58.77 & 159.02 \\ 84 & 101.19 & 147.24 & 142.54 & 101.7 & 58.38 & 145.90 \\ 85 & 85.71 & 159.97 & 110.34 & 88.4 & 48.92 & - \\ 86 & 109.52 & 147.77 & 110.06 & 78.4 & 45.15 & -\end{array}$


Table A-4

Budget

Deficit

$\begin{array}{rr}61 & 3.79 \\ 62 & 6.80 \\ 63 & 6.59 \\ 64 & 5.60 \\ 65 & 2.87 \\ 66 & 3.65 \\ 67 & 1.83 \\ 68 & 1.72 \\ 69 & 1.28 \\ 70 & 2.03 \\ 71 & 4.58 \\ 72 & 6.10 \\ 73 & 8.60 \\ 74 & 8.52 \\ 75 & 15.59 \\ 76 & 10.56 \\ 77 & 5.04 \\ 78 & 6.67 \\ 79 & 6.65 \\ 80 & 8.56 \\ 81 & 17.97 \\ 82 & 18.78 \\ 83 & 17.76 \\ 84 & 13.79 \\ 85 & 5.10 \\ 86 & 4.70 \\ & \end{array}$

Interest on

foreign debt
Interest on

conestic debt
Uperational

Deficit

3.71

6.71

6.50

5.48

2.79

3.57

1.77

1.65

1.22

1.62

4.10

5.54

8.06

7.73

14.90

9.08

3.90

4.74

4.62

6.71

11.75

10.55

14.76

10.64

2.37 
Table A-5

\begin{tabular}{|c|c|c|c|c|c|c|c|}
\hline \multicolumn{2}{|c|}{ Inflation } & budget & Base/GDF & $\mathrm{Mi} / 6 \mathrm{DF}$ & $n 2 / 6 \mathrm{OP}$ & $\mathrm{M} 3 / \mathrm{GDF}$ & $\mathrm{M} 4 / 6 \mathrm{DP}$ \\
\hline 70 & 21.7 & 2.03 & 0.12 & 0.15 & 0.25 & 0.25 & 0.25 \\
\hline 71 & 39.1 & 4.58 & 0.10 & 0.13 & 0.22 & 0.23 & 0.23 \\
\hline 72 & 64.1 & 6.10 & 0.09 & 0.11 & 0.19 & 0.21 & 0.21 \\
\hline 73 & 43.8 & 8.60 & 0.13 & 0.11 & 0.20 & 0.22 & 0.22 \\
\hline 74 & 40.2 & 8.52 & 0.14 & 0.14 & 0.25 & 0.27 & 0.28 \\
\hline 75 & 335.1 & 15.59 & 0.16 & 0.09 & 0.14 & 0.16 & 0.17 \\
\hline 76 & 347.5 & 10.56 & 0.14 & 0.07 & 0.11 & 0.12 & 0.16 \\
\hline 77 & 160.4 & 5.04 & 0.16 & 0.06 & 0.14 & 0.15 & 0.16 \\
\hline 78 & 169.8 & 6.67 & 0.14 & 0.06 & 0.18 & 0.18 & 0.20 \\
\hline 79 & 139.7 & 6.65 & 0.09 & 0.06 & 0.19 & 0.19 & 0.21 \\
\hline 80 & 87.6 & 8.56 & 0.08 & 0.07 & 0.21 & 0.21 & 0.23 \\
\hline 81 & 131.3 & 17.97 & 0.09 & 0.05 & 0.20 & 0.20 & 0.22 \\
\hline 82 & 209.7 & 18.78 & 0.29 & 0.05 & 0.17 & 0.16 & 0.19 \\
\hline 83 & 433.7 & 17.76 & 0.29 & 0.04 & 0.13. & 0.14 & 0.14 \\
\hline 84 & 688.0 & 13.79 & 0.20 & 0.04 & 0.11 & 0.12 & 0.12 \\
\hline 85 & 385.0 & 5.10 & 0.12 & 0.40 & 0.11 & 0.11 & 0.13 \\
\hline 86 & 81.9 & 4.70 & 0.09 & 0.05 & 0.14 & 0.16 & 0.18 \\
\hline
\end{tabular}

